Ian Mason*

\title{
Translator behaviour and language usage: some constraints on contrastive studies
}

\begin{abstract}
This article concerns the phenomenon of junction, a cohesive device for signalling interclausal or inter-sentential relations, and its translation. The predominant finding of recent French-English contrastive studies on the topic of junction has been that, whereas there is a trend to junction-less juxtaposition in French, explicit co-ordination is preferred in English. Doubts concerning the universal validity of such a norm constitute the motivation for this study, which aims to consider:

(1) the status of translator behaviour as evidence of norms of language behaviour;

(2) the status of contrastive linguistics within translation studies.

Examples of translations of writings by Albert Camus are then discussed in an attempt to show that translators' decisions are sensitive to a number of contextual factors including genre, discourse and text type. My conclusions lead me to suggest some limitations on the use of quantitative studies within translation studies, including those based on analysis of machine-readable corpora.
\end{abstract}

\section{Introduction}

An earlier study of ellipsis of adversative junction in French and English (Mason 1998) led me to consider some recent contrastive studies on the topic of junction and related issues (principally Ballard (1995 a \& b), Chuquet \& Paillard (1987 \& 1992), Gallagher (1995) and GuilleminFlescher (1981)). The predominant finding of such studies has been that whereas there is a trend to junction-less juxtaposition in French, explicit coordination is preferred in English. Although such a trend is not universally accepted (see Delisle 1980: 198-99; Granger 1998), plentiful evidence of the regularity of the explicitation du marqueur de disjonction is presented by Guillemin-Flescher 1981 (with examples taken from seven

\footnotetext{
* Ian Mason

Centre for Translation and Interpreting Studies in Scotland

Heriot-Watt University

Edinburgh
} 
English translations of Madame Bovary) and by Gallagher (1995), who discusses the explicitation needed in translating into German examples such as (1) below.

(1) Un personnage? Oui, certes. La personne se révéla moins brillante. (A. Maurois)

Showing that translators into German invariably insert an explicit adversative marker (e.g. allerdings, jedoch), he also concludes that

le traducteur travaillant vers l'anglais devra donc expliciter et désambiguïser les relations intra- et inter-énoncés en utilisant des connecteurs adversatifs et concessifs. (1995: 213).

This view echoes that of Guillemin-Flescher (1981: 189): 'En anglais, il faudra, tout d'abord, expliciter la relation'.

Although such may not have been the intention of the authors, the phenomenon is presented in these studies as if it were an unconditional rule of contrastive usage in English and French, to which translators instinctively adhere. Doubts concerning the universal validity of such a rule constitute the motivation for this study, which aims to consider the status of translator behaviour as evidence of norms of language behaviour and, as a concomitant, the status of contrastive linguistics within translation studies. My conclusions lead me to suggest some limitations on the use of quantitative studies within translation studies, including those based on analysis of machine-readable corpora.

\section{Translator behaviour as evidence of norms of language behaviour}

French/English contrastive studies have claimed to detect, on the basis of empirical evidence, a number of contrasting norms of language behaviour in the two languages. The evidence in question stems largely from (predominantly literary) source texts and their translations in the other language. Ballard (1995a: 11), referring to his study of the conjunctions and and et, makes clear the methodology of this approach, which aims to:

déboucher sur une comparaison des fonctionnements des discours anglais et français en établissant à partir d'un texte et de sa traduction, un usage comparé de deux conjonctions que l'on donne généralement pour équivalentes. 
Thus, such studies aim to arrive at fairly powerful generalisations concerning language behaviour ('fonctionnements des discours') in English and French on the basis of evidence of regularities of translator behaviour. References to the value of 'pourcentages sur la fréquence d'emploi', 'chiffres précis', and so on make explicit the quantitative orientation of the studies. Likewise, Kibbee (1995: 73), in the same volume, suggests that

La comparaison de plusieurs traductions d'un même ouvrage offre une possibilité intéressante pour la comparaison de la syntaxe et de la sémantique de deux langues...

and proposes to 'dresser un bilan statistique de l'usage des deux langues'. It is important to realise, firstly, that only the work of professional translators is accepted as evidence and, secondly, that only statistically significant trends are retained, thus avoiding any conclusions based on the shaky evidence of idiosyncratic behaviour of non-typical translators. Assuming that experienced translators generally adhere to target language norms and avoid undue source-language interference, it then seems reasonable, in this view, to take regular trends in their output as evidence of trends in natural use of the target language concerned. Statistical frequency tables then add empirical weight to the findings.

Now, if translators' behaviour can be used as evidence of regularities of discoursal behaviour in both languages, then, just as translators into English appear to make explicit those cases where junction is ellipted in French so, conversely, one might expect a significant percentage of translator ellipsis of English explicit junction in English-to-French translating of the same cohesive devices. Evidence of this is, however, scarce. No examples of removal of English explicit adversative junction by translators working into French are cited in Guillemin-Flescher's study, for example. Further study of this phenomenon is needed and machine-readable corpora (cf. Salkie 1997) may provide much more systematic and reliable findings. Some indication of a general trend is, however, available from the work of Douglas Kibbee (cf. Kibbee 1995). In a section of his corpus of nineteen French translations of Alice in Wonderland, kindly made available to me by him, there is only one example (out of a total of sixty possible instances) of English explicit junction (but) becoming, in translation, ellipted junction. Implicitation, then, in English-to-French translating seems less frequent than the amply documented French-to- 
English explicitation. This impression is reinforced by statistical evidence presented by Granger (1998) from analysis of a machine-readable corpus of source texts and translations in both languages. Whereas she did find evidence of connectors being added in French-to-English translating (19.5\%), she also found that suppression of connectors in English-to-French translating was much less frequent (10\%). In other words, the evidence currently available tends to support what has become known as the explicitation hypothesis (Blum-Kulka 1986) - namely, that translators tend towards explicitation irrespective of the languages or direction of translating - rather than the hypothesis that translators respond to contrastive language norms for the use of junction.

For evidence of contrastive norms of actual language behaviour, it would seem more logical to contrast spontaneously sourced texts in each language, i.e. a contrastive textology, in the sense intended by Hartmann 1980, than to compare source texts to corresponding sets of target texts. This, of course, raises the problem of comparability: how can one demonstrate that any L1 corpus to be subjected to a statistical analysis is equivalent in nature and therefore comparable to any L2 corpus, however carefully selected? Attempts to constrain the genres, discourses or text types included inevitably run up against the problem of the culturespecific nature of textuality in any given language ${ }^{1}$. It is no doubt this difficulty which has led contrastivist researchers to resort to translations; at least here, it would seem, all variables are reasonably controlled and target texts are, in a real sense, comparable to source texts. Even here though the assumption of comparability may be erroneous. For translators are subjective individuals and, more importantly, are governed in their behaviour by the Skopos (Vermeer, e.g. 1996) of the task in which they are involved. An avowedly foreignising translation (cf. Venuti 1995) may seek to relay features of source-text expression, including traces of source-language syntax, word order, idiom, and so on. Indeed, it seems safe to assume that most translators are influenced, at least potentially and to some extent, by the form of their source text. On this basis, there must be serious questions about the validity of translator behaviour as evidence of spontaneous language use.

1 See however McLaren (2000) for evidence of contrastive regularities in companies' promotional literature in English and French. 


\section{The status of contrastive linguistics within translation studies}

At this stage it might appear that the argument being advanced here is that Contrastive Linguistics has no place within Translation Studies. And indeed there are many Translation Studies scholars who would argue that it is simply a separate discipline with distinct theoretical and methodological frameworks and different aims. From the point of view of Skopos theory, of Gideon Toury's (1995) Descriptive Translation Studies $^{2}$ and of many other contemporary trends within the field, the act of translating has nothing to do with language systems and everything to do with motivated behaviour in response to a set of stimuli. Hoey \& Houghton reflect this view when they write (in Baker 1998: 48):

Contrastive Analysis deals with systems rather than users of systems. Consequently, it tends to be relevant to translations as products rather than to the process of translating - which many current theorists (...) see as central to an adequate theory of translation.

Yet if we are to study and adequately describe translator behaviour as a distinct behaviour, it will surely be useful to have evidence of non-translational language behaviour as a yardstick against which we can measure the very specificity of the translator's action. In this sense, contrastive norms of spontaneous language behaviour in two languages constitute the background against which can be observed residual traces of SL behaviour in translating, relative degrees of domestication or foreignization (Venuti, e.g. 1995) or positioning within a polysystem

2 Toury (1995: 53): 'However highly one may think of Linguistics, Text-Linguistics, Contrastive Textology or Pragmatics and of their explanatory power with respect to translational phenomena, being a translator cannot be reduced to the mere generation of utterances which would be considered 'translations' within any of these disciplines'. And again (1995:3), in respect of Contrastive Linguistics, Contrastive Textology, Comparative Literature, stylistique comparée, ‘... while their subject matter could well have been deemed translational, the theoretical and methodological frameworks within which it was handled could not, if only because their interests lacked the wish to fully account for all that translation may, and does involve'. Cf. Also Vermeer (1996: 112): 'I think it is time to stress the independence of translation studies from mere linguistics...' For both of these scholars, it is not so much the case that Contrastive Linguistics is strictly irrelevant to Translation Studies but rather that the evidence which its study produces can only be a contribution from the outside - along with many others - to the study of translating as an activity in its own right. 
(Even-Zohar 1990). Moreover, contrastive studies involving source-totarget text comparisons do provide valuable evidence of a kind, even if they do not support strong claims about spontaneous usage. What they can of course lead to are claims about translator behaviour and, where the evidence adduced is matched against evidence from spontaneously sourced texts, we can even begin to observe what is peculiar to translator behaviour. Evidence from the studies mentioned above is consequently important and the growth of empirical studies in this area is certainly a step forward. In the remainder of this article, therefore, we shall add in a small way to this growing body of evidence, not in order to make claims about the use of the French and English languages but, rather, to point towards context-sensitive translator behaviour and to discuss the business of translating as being about motivated choice.

In the particular case of use of junction which we have been considering, most available evidence does indeed confirm a tendency among translators into English towards explicitation of ellipted junction in French. The trends towards explicitation of junction observed by Gallagher (1995) are also amply attested in the data which I have studied, as exemplified in (2) below, which extends our interest from adversative to causative junction ${ }^{3}$.

(2)

J'ai réfléchi, cela n'avait aucune

I thought it over; really it didn't seem to importance. J'ai offert une cigarette au concièrge et nous avons fumé. matter, so I offered the porter a cigarette and we both smoked.

In this ST fragment, the causality linking the reflection in sentence one to the action reported in sentence two is easily inferred on the basis of a previously mentioned topic. The fragment is taken from A. Camus's L'Etranger, at a point where Meursault is considering whether or not it is appropriate to smoke in the presence of the dead body of his mother. To this extent, the explication in the TT thus seems a fairly natural translator response. And the very regularity of this trend presumably does correspond to some perceived need for explicitness in English. But any formulation of a translational norm along these lines, simply positing

3 In all textual examples quoted, highlighting has been added to draw attention to particular uses of junction. 
this as a regularity would be a dangerous short-cut. The main problem with such an approach lies in a tendency of its proponents to elaborate context-free rules and to consider isolated sentences without regard for the rhetorical purposes which give rise to them. It is this trend, within contrastivist studies, which has to be resisted. Consideration of each case has to be sensitive to higher-level contextual and co-textual factors.

One improvement, in this respect, will be simply to acknowledge that different (ST) writers behave differently. Gallagher (1995: 218) is careful to admit, in respect of his own data that:

La tendance à l'implication est nettement marquée chez Maurois, alors que c'est la tendance opposée qui prédomine chez Sartre.

This in turn leads him to express caution about the powerfulness of any generalisations based upon his findings. Put simply, what typifies a particular writer cannot be taken as characteristic of usage in a given language as a whole. The next step involves sensitivity to the rhetorical purposes which govern any instance attested within a text. Use of language - by ST writers and by translators - is a social act. No meaningful statements can be made about utterances independently of the set of relevant circumstances in which they take place. There must be sensitivity to genres (in the sense of use of language appropriate to a given social occasion) and to discourses (in the sense of attitudinal expression conventionally associated with particular social institutions). And the overall purpose being pursued in a given sequence of text is bound to exert a determining influence upon choices made along the way.

\section{An Illustration: Junction in Albert Camus}

As an initial attempt to observe some of the phenomena we have been discussing within a richer framework, I have looked at the writings of Albert Camus and some of the translations of his works into English. What are the various motivations which may underlie different ST and TT uses? Given the status of this effort as work in progress, what follows is intended to be illustrative and no claims are being made here that what is presented constitutes conclusive evidence. It may however be sufficient for the purpose of introducing a note of caution into the formulation of research-based generalisations concerning translators' use of junction. 
We start with the phenomenon observed in (2) above, which is part of Meursault's narrative in L'Etranger (Camus 1942/1946). Fowler (1986: 96) noted that frequent ellipsis of causative junction in the detective novels of Raymond Chandler appeared to create the need for inferencing by the reader, thus heightening reader involvement. An example of this, from Chandler (1939), is given as (3) below.

(3) I went out and through the hedge and up the hill to my car and got into it. I turned it around and drove up over the crest. Nobody shot at me. After a few blocks I turned off, cut the motor and sat for a few moments. Nobody followed me either. I drove back into Hollywood.

Here, the repeated use of junction ('and') within the sentence is in contrast to its absence between sentences. Thus the link between the actions related and the thought processes which give rise to them has to be inferred by the reader.

Camus, in L'Etranger, makes frequent use of the same device. A further example is given as (4) below.

Je lui ai demandé si on pouvait éteindre une des lampes. L'éclat de la lumière sur les murs blancs me fatiguait.
The glare from the white walls was making my eyes smart, and I asked him if he couldn't turn off one of the lamps.

Without access to the 'black box' of the language user's mind, any imputation of motives to the writer (and for that matter, the translator) has to remain speculative. Nevertheless, literary critics have often referred to Meursault's confusion, his lack of self-awareness, and so on, as it emerges from the novel. Meursault is hardly self-analytical; rather, he observes actions, notes instinctive feelings and moves on. It is possible that uses such as (2) and (4) above respond to motivations of this kind. That is, the textural devices deployed respond to higher-level contextual requirements of a particular writer on a particular occasion. In both cases, the trend towards explicitation is observable in the translation. What can equally be observed, however, is that no such systematic explicitation is apparent in the work of the same translator when it comes to uses of adversative junction. Indeed, examples (5) - (8) constitute counter-examples to the hypothesis of Guillemin-Flescher (1981), Chuquet and Paillard (1987) and others, concerning junction in French and English. Here, explicit adversative junction in the ST is either changed to a different kind of junction, made less explicit or ellipted in the TT. 
(5)

...je sentais quel plaisir j'aurais pris à me promener s'il n'y avait pas eu maman. Mais j'ai attendu dans la cour, sous un platane.

(6)

J'ai encore réfléchi un peu à ces choses mais j'ai été distrait par une cloche...

(7)

"Vous comprenez, c'est un sentiment un peu puéril. Mais lui et votre mère ne se quittaient guère."

(8)

Je suis resté immobile. Mais dans la chambre du vieux Salamano, le chien a gémi sourdement.
I caught myself thinking what an agreeable walk I might have had if it hadn't been for Mother. As it was, I waited in the courtyard under a plane-tree.

I went on thinking, like this, for ten minutes or so; then, the sound of a bell...

"It's a rather touching little story in its way. He and your mother had become almost inseparable."

... for a while I stood listening to it. Then the dog began to moan in old Salamano's room...

We can note here firstly that Camus, in this work, makes frequent use of explicit adversative junction (in the form of sentence-initial or interclausal mais), despite our observations above concerning the use of implicature to encourage inferencing; and secondly that a particular translator may, for the sake of creating a cohesive and coherent TT in its own right, revise or reinterpret ST junction. While no claim is made that either Camus as writer of L'Etranger or this particular translator ${ }^{4}$ always conform to this behaviour, (5) - (8) above may be said to be not unrepresentative of the two works as a whole. It is also of course the case that each text - ST and TT - is cohesive and coherent in its own terms. The expectation that ST cohesive use is necessarily, or even desirably, transferable to a TT is, in itself, a naive one, stemming from a view of translating as language transfer rather than as motivated behaviour within a particular context and responding to its own norms. This then constitutes the first restriction on text-to-text contrastivism: any presupposed norm of identity of junction between ST and TT, from which other cases constitute a departure, is based on a mistaken view of the act of translating.

4 In the case of examples (2) and (4) - (7), this is Stuart Gilbert, The Outsider, Hamish Hamilton 1946. 
The two further restrictions to be introduced here relate respectively to the behaviour of the ST producer and the behaviour of the translator. Having observed that Camus's ellipsis of causative junction is not necessarily generalisable to other types of junction, we may further note that it does not apply to Camus in other genres, discourses or texts. Needless to say, Camus does not always write in the genre of the first-person récit. In his philosophical essays, a radically different use of junction is immediately noticeable. Fragment (9) is from L'Homme révolté (Camus 1951/1953).

(9)

Si donc nous prétendons nous installer dans l'attitude absurde, nous devons nous préparer à tuer, donnant ainsi le pas à la logique sur des scrupules que nous estimerons illusoires. Bien entendu, il y faudrait quelques dispositions. Mais, en somme, moins qu'on ne croit, si l'on en juge par l'expérience. Du reste, il est toujours possible, comme cela se voit ordinairement, de faire tuer. Tout serait donc réglé au nom de la logique si la logique y trouvait vraiment son compte.

Hence, if we profess the absurdist position, we should be ready to kill, thus giving logic more weight than scruples we consider illusory. Certainly, some compromises will be necessary. But, on the whole, fewer than one might suppose - to judge from experience. Besides, it is always possible, as we see every day, to have the killing done for one. Thus everything would be settled in accordance with logic, if logic were really satisfied.

In itself, sample (9), with its intensive use of explicit junction, constitutes counter-evidence to any generalisation concerning a tendency towards ellipsis of junction in French. Here is one genre at least - the treatise - in which inter-clausal logical relations tend to be explicitly supported. And here is one instance at least in which a translator has felt the need to reflect ST junction very closely, no doubt again for reasons of appropriateness to TL genre.

What is true of genres is true of discourses. In La Peste (Camus 1947/ 1948), the genre is the third-person narrative and the discourse which Camus uses for the narrator, Dr. Rieu, is not that which he employs in the case of Meursault. The educated medical professional's use of junction is more subtle, as evidenced in (10) and (11) below, instances in which Rieu is narrating, in a detached fashion, occurrences which he had either witnessed (10) or had related to him (11). 
(10)

“ (...) si, par exemple, il vous prenait l'envie de recommencer..."

Mais Cottard dit, au milieu de ses larmes, qu'il ne recommencerait pas.

(11)

Tarrou semblait ensuite avoir été favorablement impressionné par une scène qui se déroulait souvent au balcon qui faisait face à sa fenêtre. Sa chambre donnait en effet sur une petite rue transversale où des chats dormaient à l'ombre des murs. Mais tous les jours après déjeuner.. un petit vieux apparaissait sur un balcon, de l'autre côté de la rue.
'(...) if you took it into your head to have another shot at it.'

Cottard assured him tearfully that there wasn't the least risk of that;

We gather that Tarrou was agreeably impressed by a little scene that took place daily on the balcony of a house facing his window. His room at the hotel looked onto a small side street and there were always several cats sleeping in the shadow of the walls. Every day, soon after lunch... a dapper little old man stepped out on to the balcony on the other side of the street.

What is significant here is that, given the variety of use of junction already apparent (ellipted or simple in L'Etranger, intensive and explicit in L'Homme révolté, explicit but not straightforward in La Peste), contrastive research findings will need to be stated in a discourse-sensitive as well as a genre-sensitive way. Moreover, despite the loss of explicit junction, there is no apparent loss of coherence in the translated versions, thus belying any claim about the need for explicit junction in English.

Finally, the textual patterns underlying use of a given text type such as narrating also bear on use of junction. In L'Exil et le royaume (Camus 1957/1958), the rhetorical purpose of narrating is served in the ST, here and there, by a particularly marked style, involving absence of junction and juxtaposition of noun phrases, exemplified in (12) and (13) below, relaying an additional value of inevitability to the sequence of events narrated.

Tout d'un coup, en plein été justement, la guerre, Marcel mobilisé puis réformé, la pénurie des tissus, les affaires stoppées, les rues désertes et chaudes.
Suddenly, in summer as it happened, the war, Marcel called up then rejected on grounds of health, the scarcity of piecegoods, business at a standstill, the streets empty and hot. 
(13)

Vingt jours de grève, les femmes tristes à la maison, deux ou trois d'entre eux découragés, et pour finir, le syndicat avait conseillé de céder, sur la promesse d'un arbitrage et d'une récupération des journées de grève par des heures supplémentaires.
Twenty days on strike, the wives sad at home, two or three of them discouraged, and, in the end, the union had advised them to give in on the promise of arbitration and recovery of the lost days through overtime.

L'Exil et le royaume has often been referred to as an exercise in style and this particular way of fulfilling a narrative purpose is something which the translator has apparently felt to be worth relaying in translation, in defiance of any notion of adhering to stereotypic TL norms. Our second restriction on contrastivist studies is now clear: generalisations made on the basis of research findings should not apply to a whole language, nor should they apply to the undifferentiated work of a single writer; they must, instead, be context-sensitive and responsive to the constraints of genre, discourse and text (or overall rhetorical purpose).

The evidence presented so far also permits us to elaborate our third and final restriction on contrastive studies, namely that since different translators on different occasions respond to a different perceived skopos, translator behaviour is variable and therefore evidence from the work of different translators should not be conflated for the purpose of making generalisations about 'Camus (or any other text producer) in translation'. Stuart Gilbert, the translator whose work is illustrated in fragments (2), (4) - (8) and (10) - (11) above, is a well-known domesticator ${ }^{5}$. His use of junction, especially in The Plague (Camus 1948) is very unpredictable. By way of contrast, the use of junction by the translators Anthony Bower (see example (9) above) and Justin O'Brien (see (12) and (13) above) is scrupulously close to that of the ST.

To account for such variable data, the analyst needs to take into consideration a number of factors beyond the words-on-the-page, including:

5 For further comment on Gilbert's translation of L'Etranger in contrast to that of another translator, see Venuti 2000: 474-77, a discussion which highlights the influence of early twentieth-century American writers on Camus's style. The parallel drawn above to the style of Raymond Chandler goes in the same direction. 
- The interaction of elements within texts. For example, how do users read off the intentions behind ellipted junction - a phenomenon which is not uncommon and which takes place in English ${ }^{6}$ as well as in French? In order for intended meanings to be inferred, as we have suggested elsewhere (Mason 1998), a constant process of matching - of text elements to each other and of text elements to assumptions made about the context in which they occur - takes place. In the case of (7) above, the presence in the ST of the negatively evaluative puéril contrasts with the positively evaluated lui et votre mère ne se quittaient guère, thus motivating the presence between these two items of the junctive mais. In the TT, on the other hand, the corresponding epithet rather touching is positively evaluated and consequently supports the reported fact that He and your mother had become almost inseparable. The absence of explicit junction is entirely compatible with TL norms for what are, here, additive relations.

- The motivations of translators who, like ST producers, make use of cohesive devices in the service of higher-level purposes, including the communicative goals of the TT to be produced.

- The translator's orientation or skopos (e.g. domestication or foreignization), such as a perception of the prevalence of ST style in L'Exil et le royaume and a corresponding intention to relay it in the TT.

\section{Conclusion}

In the course of our analysis, we have been led towards several conclusions relating to contrastive studies. We have firstly cast doubt on the value of ST/TT comparisons for the purpose of deriving generalised statements about characteristics of spontaneous language behaviour. Conversely, we have suggested that, if the same kind of contrastive study is to be used for the purpose of describing regularities of translator behaviour, then such study is subject to a number of restrictions having to do with (i) avoiding any assumption that lack of correspondence between ST and TT texture constitutes a departure from some norm; (ii) ensuring that research is conducted and findings stated in a way which

6 For a striking example, see Hatim 1997: 57. 
is sensitive to such constraints as those of genre, discourse and text function; (iii) acknowledging that translator behaviour responds to skopos (or purpose) and is therefore variable in a motivated way both from translator to translator and from task to task within a given translator's output.

Now, if constraints on translating particular syntactic features are, as I have suggested, sensitive to genre (for example), what is the point (or rather, what is the potential) of deriving statistically-driven generalizations about translator behaviour from corpora in which genres, discourses and rhetorical purposes (of ST and of TT producer) are lumped together? Quantitative translation studies using machine-readable corpora are, without doubt, a new direction with immense potential within the discipline as a whole. As work in corpus linguistics has already shown, they make possible reliable generalisations on a scale previously unheard of (cf. Granger 1998; Olohan and Baker, forthcoming). All the more reason, therefore, to ensure that this new field of investigation is launched on a sound basis. For the current problem of the machine-readable corpus approach to Translation Studies, as I see it, is this: that it encourages generalisations to be made at a higher (i.e. vaguer) level of comparison (for the sake of statistical validity) than that which would be most meaningful. In the case of that area of cohesion which we call junction, this would mean findings about explicit or ellipted junction in English and in French, say, or in Writer X or Writer Y. But what we really need to discover, I would suggest, is: what are the pragmatic constraints on the use of junction within particular discourses, genres and text designs? Such an investigation calls for qualitative analysis (to complement quantitative analysis) and notes absences in texts as well as (countable) surface occurrences.

\section{References}

Baker, M. (1998). Encyclopedia of Translation Studies. London: Routledge.

Ballard, M. (ed.) (1995a). Relations discursives et traduction. Lille: Presses Universitaires de Lille.

Blum-Kulka, S. (1986). Shifts of cohesion and coherence in translation. In J. House \& S. Blum-Kulka (eds.) Interlingual and Intercultural Communication: Discourse and Cognition in Translation and Second Language Acquisition Studies. Tübingen: Narr. 
Camus, A. (1942). L'Etranger. Paris: Gallimard.

(1946). The Outsider, trans. S. Gilbert. London: Hamish Hamilton.

(1947). La Peste. Paris. Gallimard.

(1948). The Plague, trans. S.Gilbert. London: Hamish Hamilton.

(1951). L'Homme révolté. Paris: Gallimard.

(1953). The Rebel, trans. A.Bower. London: Hamish Hamilton.

(1957). L'Exil et le royaume. Paris: Gallimard.

(1958). Exile and the Kingdom, trans. J.O'Brien. London: Hamish Hamilton.

Chandler, R. (1939). The Big Sleep. London: Hamish Hamilton.

Chuquet, H. \& M. Paillard (1987). Approche linguistique des problèmes de traduction. Paris: Ophrys.

(1992). Enonciation et traduction chez les linguistes francophones, Journal of French Language Studies 2, 237-259.

Delisle, J. (1980). L’Analyse du discours comme méthode de traduction. Ottawa: University of Ottawa Press.

Even-Zohar, I. (1990). The Position of Translated Literature within the Literary Polysystem. Poetics Today 11: 45-51.

Fowler, R. (1986). Linguistic Criticism. Oxford: Oxford University Press. 2nd. ed. 1996.

Gallagher, J. (1995). L'Effacement des connecteurs adversatifs et concessifs en français moderne. In Ballard (ed.), 201-220.

Granger, S. (1998). Linguistique de corpus et traduction. Les Connecteurs logiques anglais-français. Unpublished conference paper delivered at the Association for French Language Studies workshop on Translation and Contrastive Studies, University of Surrey, February 1998.

Guillemin-Flescher, J. (1981). Syntaxe comparée du français et de l'anglais. Problèmes de traduction. Paris: Ophrys.

Hartmann, R. (1980). Contrastive Textology. Heidelberg: Julius Groos.

Hatim, B. (1997). Communication across Cultures. Translation Theory and Contrastive Text Linguistics. Exeter: University of Exeter Press.

Kibbee, D. (1995). Assertion/atténuation, subjectivité/objectivité en anglais et en français: “seem/sembler". In Ballard (ed.), 73-87.

Mason, I. (1998). Discourse connectives, ellipsis and markedness. In L. Hickey (ed.) The Pragmatics of Translation. Clevedon: Multilingual Matters.

McLaren, Y. (2000). The Discourse of Company Advertising in France and the United Kingdom: A Contrastive Textology. Unpublished PhD. thesis, Heriot-Watt University, Edinburgh.

Olohan, M. and M. Baker (forthcoming). Reporting that in translated English: evidence for subconscious processes of explicitation. Across Languages and Cultures. 
80

Salkie, R. (1997). Naturalness and contrastive linguistics. In B. LewandowskaTomaszczyk \& P.J.Melia (eds.) PALC '97. Practical Applications in Language Corpora. Lodz: Lodz University.

Toury, G. (1995). Descriptive Translation Studies and beyond. Amsterdam/Philadelphia: John Benjamins.

Venuti, L. (1995). The Translator's Invisibility. London: Routledge. (ed.) (2000). The Translation Studies Reader. London: Routledge.

Vermeer, H. (1996). Skopos Theory. Some arguments for and against. Heidelberg: TextconText. 